isotope stage 5e) Indian Ocean variance is low (for example, core $\mathrm{RC} 17-98,13.22^{\circ} \mathrm{S}, 65.60^{\circ} \mathrm{E} ; 0.18^{\circ} \mathrm{C}$ ) whereas that for the Atlantic is high (for example, core RC13-228, $22.33^{\circ} \mathrm{S}, 11.20^{\circ} \mathrm{E} ; 6.1^{\circ} \mathrm{C}$ ). Recent analyses of southeastern Atlantic marine sediments have identified repeated short-lived ( $\sim 5-10 \mathrm{kyr})$ periods of low SSTs ${ }^{26}$, three of which correspond to periods of enhanced aridity in the Mega Kalahari. We propose that changes to the SST gradient and hence the northeast-southwest rainfall gradient are likely to originate in the Atlantic.

We have shown that the Mega Kalahari sedimentary system has exhibited a complex response to changes in Quaternary climates. Similar complexity can be expected in other low-latitude areas where extensive dune systems are preserved, which could provide critical information for GCM validation and inter-regional comparison; but direct chronologies of the development of such areas have not yet been established.

Received 12 September 1996; accepted 23 May 1997.

1. Sarnthein, M. Sand deserts during glacial maximum and climatic optimum. Nature 272, 396-398 (1978).

2. Sarnthein, M. \& Koopman, B. Late Quaternary deep-sea record on northwest African dust supply and wind circulation. Palaeoecol. Afr. 12, 238-253 (1980).

. Street-Perrott, F. A., Marchand, D. S., Roberts, N. \& Harrison, S. P. Global Lake Level Variations from 18,000 to 0 Years Ago: A Palaeoclimatic Analysis (Tech. Rep. TR046, US Dept of Energy, Washington DC, 1989)

4. de Menocal, P. B., Ruddiman, W. F. \& Pokras, E. M. Influences of high- and low-latitude processes on African terrestrial climate: Pleistocene eolian records from equatorial Atlantic ocean drilling program Site 663. Paleoceanography 8, 209-242 (1993).

Thomas, D. S. G. \& Shaw, P. A. The Kalahari Environment (Cambridge Univ. Press, 1991).

6. Cohen, A. L. \& Tyson, P. D. Sea-surface temperature fluctuations during the Holocene off the south coast of Africa: implications for terrestrial climate and rainfall. Holocene 5, 304-312 (1995).

Cockcroft, M. J., Wilkinson, M. J. \& Tyson, P. D. The application of a present day climatic model to the late Quaternary in Southern-Africa. Clim. Change 10, 161-181 (1987).

8. Van Zinderen Bakker, E. M. Comparison of late Quaternary climate change evolutions in the Sahara and the Namib-Kalahari region. Palaeoecol. Afr. 12, 381-394 (1980).

. Huntley, D. L., Godfrey-Smith, D. I. \& Thewalt, M. L. W. Optical dating of sediment. Nature 313, 257267 (1985).

10. Henderson-Sellers, A. \& Hansen, A.-M. Climate Change Atlas: Greenhouse Simulations from Model Evaluation for Climate Assessment (Kluwer, Dordrecht, 1995).

11. Schneider, S. H. (ed.) Encyclopedia of Climate and Weather (Oxford Univ. Press, New York, 1996).

12. Livingstone, I. \& Thomas, D. S. G. in The Dynamics and Environmental Context of Aeolian Sedimentary Systems (ed. Pye, K.) 91-103 (Geol. Soc. London, 1993).

13. Wiggs, G. F. S., Thomas, D. S. G., Bullard, J. E. \& Livingston, I. Dune mobility and vegetation cover in the southwest Kalahari desert. Earth Surf. Proc. Landf. 20, 515-530 (1995).

14. Thackeray, J. F. \& Lee Thorpe, J. A. Isotopic analysis of equid teeth from Wonderwerk Cave, Northern Cape Province, South Africa Palaeogeogr. Palaeoclimatol. Palaeoecol. 99, 141-150 (1992).

15. Partridge, T. C. et al. Late Pleistocene and Holocene climatic change in Southern Africa. S. Afr. J. Sci. 86, 302-306 (1990)

16. Shaw, P. A. \& Thomas, D. S. G. The Quaternary palaeoenvironmental history of the Kalahari, Southern Africa. J. Arid Environ. 32, 9-22 (1996).

17. Brookes, G. A., Cowart, J. B. \& Marais, E. Wet and dry periods in the southern African summer rainfall zone during the last $300 \mathrm{kyr}$ from speleothem, tufa and sand dune age data. Z. Fur. Geom. (in the press).

18. Bloemendal, J. \& de Menocal, P. Evidence for a change in the periodicity of tropical climate cycles at 2.4 Myr from whole-core magnetic susceptibility measurements. Nature 342, 897-900 (1989).

19. Street-Perrott, F. A. \& Perrott, R. A. Abrupt climate fluctuations in the tropics: the influence of Atlantic Ocean circulation. Nature 343, 607-612 (1990)

20. de Menocal, P. \& Rind, D. Sensitivity of Asian and African climate to variations in seasonal insolation, glacial ice cover, sea surface temperature, and Asian orography. J. Geophys. Res. 98, 7267-7287 (1993).

21. Avery, D. M. Late Pleistocene coastal environment of the southern Cape Province of South Africa micromammals from Klasies River mouth. J. Archaeol. Sci. 14, 405-412 (1987).

22. Miller, D. F., Yates, R. J., Parkington, J. E. \& Vogel, J. C. Radiocarbon-dated evidence relating to a mid Holocene relative high sea-level on the south-western Cape Coast, South Africa. S. Afr. J. Sci. 89, 35 44 (1993).

23. Sifeddine, A. et al. La sédimentation organique lacustre en zone tropicale sud au cours des 36000 dernières années (Lac Tritrivakely, Madagascar). C. R. Acad. Sci., Ser. IIa 321, 385-391 (1995).

24. Kutzbach, J. E., Guetter, P. J., Behling, P. J. \& Selin, R. in Global Climates Since the Last Glacial Maximum (eds Wright, H. E. et al.) 24-93 (Univ. Minnesota Press, 1993).

25. Imbrie, J. \& Duffy, A. SPECMAP Archive (NOAA Palaeoclimatology Program, Natl Geophys. Dat Center, Boulder, CO, 1993)

26. Little, M. G. et al. Trade wind forcing of upwelling, seasonality, and Heinrich events as response to sub-Milankovitch climate variability. Paleoceanography (in the press).

27. Aitken, M. J. Thermoluminescence Dating (Academic, London, 1985).

28. Stokes, S. Optical dating of selected late Quaternary aeolian sediment from the southwestern United States. Thesis, Oxford Univ. (1994).

Acknowledgements. We thank P. Shaw and G. Haynes for discussions; M. Malifa, M. Moore, B. Adder P. O'Connor, G. Wiggs, E and K. Walker for technical and field assistance; P. Hayward for drafting assistance; G. A. Brookes, M. Little and D. Kroon for providing access to unpublished data; M. J. Aitken, A. K. Singhvi and C. K. Folland for advice on wider aspects of the research programme; and D. Sexton for help with model data. This work forms part of a wider project on southern African palaeoenvironments funded in part by the Trapnell Fund, the Universities of Oxford and Sheffield; R. Washington was supported by the DOE.

Correspondence and requests for materials should be addressed to S.S. (e-mail: stephen.stokes@ geography.ox.ac.uk).

\section{Sensitivity of earthquake cycles on the San Andreas fault to small changes in regional compression}

\author{
Chi-yuen Wang ${ }^{\star}$ \& Yongen Cai $\dagger$
}

* Department of Geology \& Geophysics, University of California, Berkeley, California 94720, USA

$\dagger$ Department of Geology, Peking University, Beijing 100871, China

The current pattern of slip ${ }^{1,2}$ within the San Andreas fault system in the San Francisco Bay area is distinctly different from the longterm slip pattern inferred from the geological record ${ }^{3,4}$. This difference is not surprising because geological data record the accumulated displacements over many earthquake cycles, whereas geodetic data reveal the present-day slip pattern. It is not known, however, what mechanism triggers the change from the interseismic' slip pattern (when the San Andreas fault is locked) to the 'co-seismic' slip pattern (when the San Andreas fault ruptures in earthquake slip). Here we use numerical simulations of the entire seismic cycle on this complex fault system to show that the San Andreas fault may be in a critical state and sensitive to small perturbations in regional compression. In particular, we find that small increases in regional compression may lock the San Andreas fault, whereas small decreases in regional compression may release the locked segment and so permit co-seismic slip. This sensitivity suggests that cyclic changes in the regional stress field resulting from plate convergence and thrust faulting in the Coast Ranges could trigger major earthquakes on the San Andreas fault.

In the past decade, it has become clear that a regional compression subnormal to the San Andreas fault system (Fig. 1a) occurs in coastal California ${ }^{5,6}$. This compression may be due to a small oblique convergence between the Pacific and the North American plates since 3.4-3.9 $\mathrm{Myr} \mathrm{ago}^{7}$, producing thrust faulting ${ }^{8-11}$ (Fig. 1b) and thrust earthquakes ${ }^{12}$ in the Coast Ranges. Several plate-motion models ${ }^{13-15}$ also show the presence of a small fault-normal component in the 'San Andreas discrepancy'. The average magnitude of this compression, inferred from stress orientation and surface heat flow, is ${ }^{5} \sim 100 \mathrm{MPa}$. Continuing, oblique plate convergence ${ }^{7}$ may cause the compression to increase slowly, whereas thrust faulting in the Coast Ranges may cause it to decrease intermittently; the magnitude of compression will therefore fluctuate with time (Fig. 1c).

The relative motion between the Pacific and the North-American plates drives the deformation in coastal California. A finite-element method is used to simulate this process. The model is a map-view layer of the seismogenic crust in central California ${ }^{16}$; it extends from Parkfield in the south to Point Arena in the north, and from the Pacific basin in the west to the Sierra Nevada foothills in the east. As the lateral dimensions of the model $(350 \mathrm{~km}$ in the east-west direction and $450 \mathrm{~km}$ in the north-south direction) are much greater than the thickness of the seismogenic layer $(10-15 \mathrm{~km})$, a thin-plate approximation may be adopted. The base of this plate coincides with a master detachment beneath the San Francisco Bay area $^{17}$. Calculation based on the crustal structure of central California $^{18}$, the geotherm of the San Francisco Bay area ${ }^{19}$, and the rheological properties of crustal minerals ${ }^{20}$ suggests that the detachment may correspond to a depth of minimum strength. Furthermore, pore pressure in many exploration wells in the region is nearly lithostatic ${ }^{21}$; thus the effective vertical stress may be small and a plane stress analysis may be appropriate. The geographical locations 
of the major faults (Fig. 2) are taken from existing fault maps ${ }^{22,23}$. Slip on the faults is assumed to obey Coulomb's friction law, with an effective frictional coefficient of 0.2 (refs 5, 6, 24). The upper-crustal blocks are assumed to behave as elastoplastic solid ${ }^{16,25}$. Viscous relaxation of the crust and faults ${ }^{26}$ is not considered.

As boundary conditions, a constant displacement rate of $39 \mathrm{~mm} \mathrm{yr}^{-1}$ (ref. 16) along $\mathrm{N} 30^{\circ} \mathrm{W}$ is imposed on the Pacific model boundary. At the same time, an effective compression of $100 \mathrm{MPa}$ (ref. 5) is applied normal to this boundary. South of Hollister, the San Andreas system converges to a single strand. At latitudes of $36-37^{\circ} \mathrm{N}$, the fault creeps at a constant rate of $33 \mathrm{~mm} \mathrm{yr}^{-1}$ (ref. 2). A displacement boundary condition of $33 \mathrm{~mm} \mathrm{yr}^{-1}$ parallel to the San Andreas fault is thus applied on the southern boundary west of the San Andreas fault. This model ${ }^{16}$ correctly predicts the Quaternary fault slip rates (see also Table 1), the regional stress orientation, and the locations of crustal failure in the region; it is used as the starting model in this study.

We carried out four sets of numerical experiments. In the first experiment, two incremental steps, each with a shear displacement of $\Delta u=39 \mathrm{~m}$ (equivalent to time steps of 1,000 yr each), are applied on the Pacific model boundary; the normal force on the boundary is kept constant. The resulting slip pattern (not shown) in each step is identical to that in the starting model (Fig. 2a), demonstrating a quasi-steady fault-slip pattern under the imposed condition.

In the second experiment, an increase in shear displacement of $\Delta u=39 \mathrm{~m}$ (equivalent to a time step of $100 \mathrm{yr}$ ) and an increase in normal compression $\Delta P$ are applied on the Pacific boundary of the starting model. At $\Delta P=0.1 \mathrm{MPa}$, the slip rate on the San Andreas fault (not shown) declines but remains the greatest in the area. At $\Delta P=0.5 \mathrm{MPa}$, the fault segment between San Francisco and Hollister becomes locked (Fig. 2b), and the Hayward and the Calaveras faults become the fastest slipping faults in the system. We note the broad similarity between this slip pattern and the current inter-seismic slip pattern determined from geodetic measurements (Table 1 ). We also note that the magnitude of $\Delta P$ that is required to lock the San Andreas fault is similar to the stress drop in thrust earthquakes in the Coast Ranges ${ }^{27}$. The stable transition from one experiment to another demonstrates the robustness of the solution.

The third experiment is identical to the second, except that $\Delta P$ and $\Delta u$ are both increased by a factor of 10 , while the ratio $\Delta P / \Delta u$ is kept constant. The resulting slip pattern (not shown) is identical to that in the previous experiment. This suggests that the ratio between $\Delta P$ and $\Delta u$, rather than their individual magnitudes, controls the slip pattern. Increasing the ratio tends to lock the San Andreas fault, whereas decreasing the ratio allows the fault to slip.

Last, we examine how the slip pattern may respond to a release of the regional compression, which may be caused by thrust faulting in the Coastal Ranges (Fig. 1c). We simulate this release by an abrupt reduction in compression at the Pacific model boundary of the inter-seismic model (Fig. 2b). The magnitude of this reduction $(-0.5 \mathrm{MPa})$ is the same as that in the increase in compression required to lock the San Andreas fault. In response, the crustal blocks bounding the San Andreas fault abruptly accelerates in rightlateral motion (Fig. 2c), suggesting a transition from an interseismic state to a co-seismic slip; we note that during this event all the other faults in the system are locked. The maximum slip occurs on the San Andreas fault segment located on the San Francisco peninsula, where the fault was locked in the previous experiment. However, significant co-seismic slip occurs along the entire modelled San Andreas fault, extending both to the north and to the south, reaching the boundaries of the modelled domain.

The simulated inter-seismic (Fig. 2b) and co-seismic slip patterns (Fig. 2c) may be repeated with small increase/decrease in the regional compression. The long-term average of these repeated patterns is supposed to produce the geological slip pattern (Fig. 2a). The different responses of the San Andreas and the Hayward
Table 1 Observed and calculated slip rates at four crossings of the major faults of the San Andreas fault system

\begin{tabular}{|c|c|c|c|c|c|c|c|c|}
\hline \multirow[t]{2}{*}{ Faults } & \multicolumn{2}{|c|}{ San Gregorio } & \multicolumn{2}{|c|}{ San Andreas } & \multicolumn{2}{|c|}{$\begin{array}{c}\text { Rodgers Creek/ } \\
\text { Hayward }\end{array}$} & \multicolumn{2}{|c|}{$\begin{array}{c}\text { Green Valley/ } \\
\text { Concord/ } \\
\text { Calaveras }\end{array}$} \\
\hline & Obs. & Calc. & Obs. & Calc. & Obs. & Calc. & Obs. & Calc. \\
\hline \multicolumn{9}{|l|}{ Inter-seismic } \\
\hline North & - & - & $0.6 \pm 0.1$ & 1 & $2 \pm 2$ & 3 & $5 \pm 1$ & 4 \\
\hline North-central & 0 & 0 & 0 & 0 & $5 \pm 1$ & 3 & $3 \pm 1$ & 4 \\
\hline South-central & 0 & 0 & 0 & 0 & $9 \pm 1$ & 7 & $3 \pm 1$ & 4 \\
\hline South & 0 & 1 & $11 \pm 3$ & $0-14^{*}$ & - & - & $12 \pm 6$ & 14 \\
\hline \multicolumn{9}{|l|}{ Geological } \\
\hline North & - & - & $24 \pm 4$ & 24 & $8 \pm 2$ & 8 & $6 \pm 2$ & 4 \\
\hline North-central & $7 \pm 1$ & 4 & $19 \pm 4$ & 18 & $9 \pm 1$ & 8 & $6 \pm 2$ & 4 \\
\hline South-central & $7 \pm 1$ & 4 & $19 \pm 4$ & 15 & $9 \pm 1$ & 8 & $8 \pm 2$ & 10 \\
\hline South & $7 \pm 1$ & 4 & $22 \pm 6$ & 24 & - & - & $12 \pm 2$ & 10 \\
\hline
\end{tabular}

All slip rates are given in $\mathrm{mm}^{-1} \mathrm{r}^{-1}$. The locations of these crossings within the San Francisco Bay area are shown in Fig. 2 a.

* This crossing is located between the locked and the creeping segments on the San Andreas fault; the cited range represents slip rates in this transition.

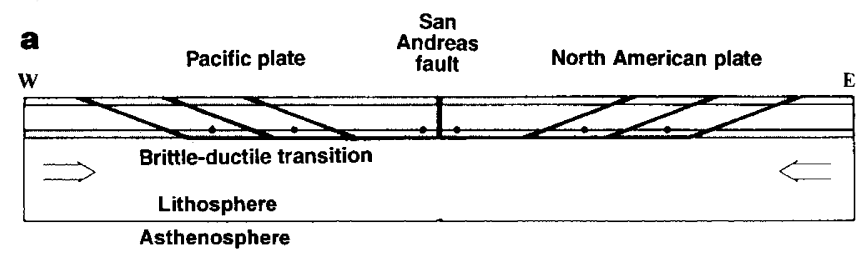

b

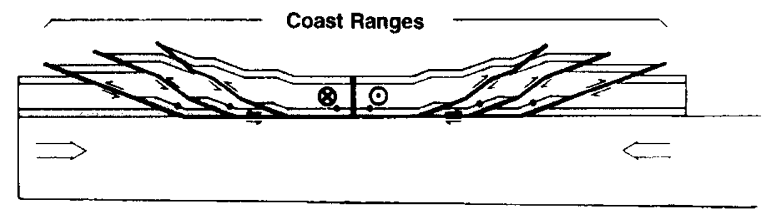

$\mathbf{C}$

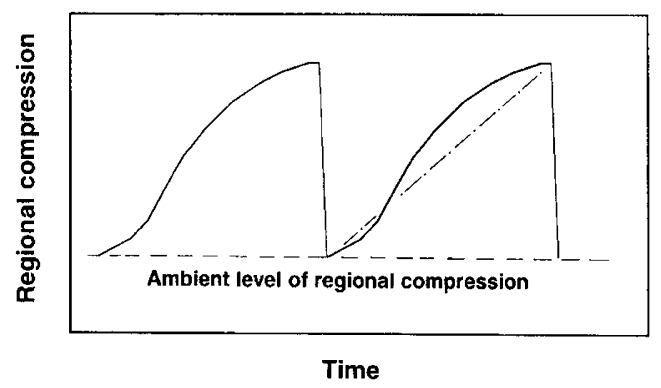

Figure 1 Schematic diagram illustrating fluctuations in regional compression in the San Francisco Bay area. a, Increase in the regional compression due to current oblique convergence between the Pacific and the North American plates (modified from ref. 10). The San Andreas fault is locked in this stage. b, Release in compression owing to thrust faulting in the Coast Ranges. In response, the crustal blocks bounding the San Andreas fault accelerate in right-lateral motion, as indicated by the symbols. c, Schematic diagram to show temporal fluctuations in the regional compression corresponding to the tectonic cycle presented in $\mathbf{a}$ and $\mathbf{b}$. The amplitude of the fluctuations in compression are exaggerated; they may be minute relative to the ambient compression (see text). The increase in compression may be gradual and nonlinear with respect to time; the decrease in compression, on the other hand, may be abrupt. 
Figure 2 a, Slip pattern in the starting model ${ }^{16}$ for this study, which agrees closely with the Quaternary slip pattern on major faults in the region (Table 1). The four paths marked in thick lines showing crossings with major faults are, from the top downwards, the North path, the North-central path, the South-central path and the South path. CC, Concord fault; CL, Calaveras fault; GN, Greenville fault; GV, Green Valley fault; HW, Hayward fault; RC, Rodgers Creek fault; SA, San Andreas fault; SF, San Francisco; SG, San Gregorio fault. b. Slip pattern after applying $\Delta P=0.5 \mathrm{MPa}$ and $\Delta u=3.9 \mathrm{~m}$ on the Pacific boundary of the starting model. A large segment of the San Andreas fault bordering the San Francisco Bay region becomes locked (indicated by the asterisks); the Hayward and the Calaveras become the fastest slipping faults in the system. This slip pattern is broadly similar to the current inter-seismic pattern determined from geodetic measurements (Table 1). c, Slip pattern after applying $\Delta P=-0.5 \mathrm{MPa}$ and $\Delta u=0$ on the Pacific boundary of the interseismic model (b). The equivalent time step is $\Delta t=0$, that is, decrease in compression takes place suddenly. In response, the crustal blocks bounding the San Andreas fault abruptly accelerate in right-lateral motion, suggesting co-seismic slip. Meanwhile, all the other faults in the system are locked.

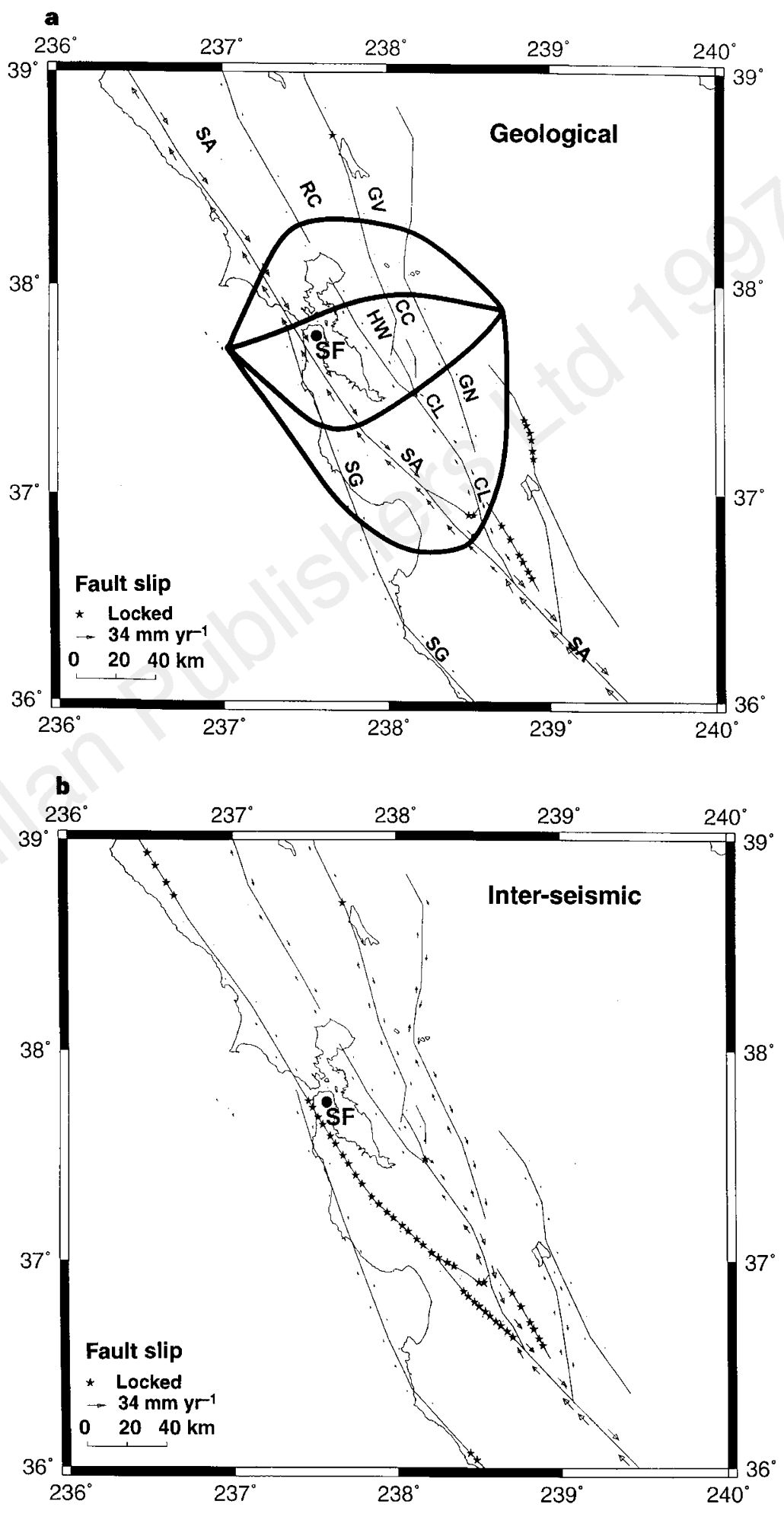

faults to the changes in the regional compression may have a simple explanation. The average azimuth of the San Andreas fault on the San Francisco peninsula is a few degrees anticlockwise from the direction of the relative plate motion ${ }^{28}$. Consequently, the regional compression has a component on the San Andreas fault in the direction opposing its right lateral motion. So when this component increases in magnitude with increasing regional compression, it may lock this segment of the San Andreas fault. On the other hand, the Hayward fault strikes $\sim \mathrm{N} 30^{\circ} \mathrm{W}$ and is thus nearly parallel to the plate-motion direction. Hence the fluctuations in the regional compression would have little effect on the force component parallel to the fault.

Evidence in support of the suggestion that thrust faulting in the region may trigger earthquakes on the San Andreas fault exists in the historical earthquake record. Both the 1906 San Francisco and the 1989 Loma Prieta earthquakes on the San Andreas fault were preceded by several years of accelerated seismic moment releases in the Coast Ranges ${ }^{29}$. In addition, immediately following the 1983 Coalinga thrust earthquake, which occurred in the Coast Ranges at a distance of $35 \mathrm{~km}$ from the San Andreas fault, accelerated slip 


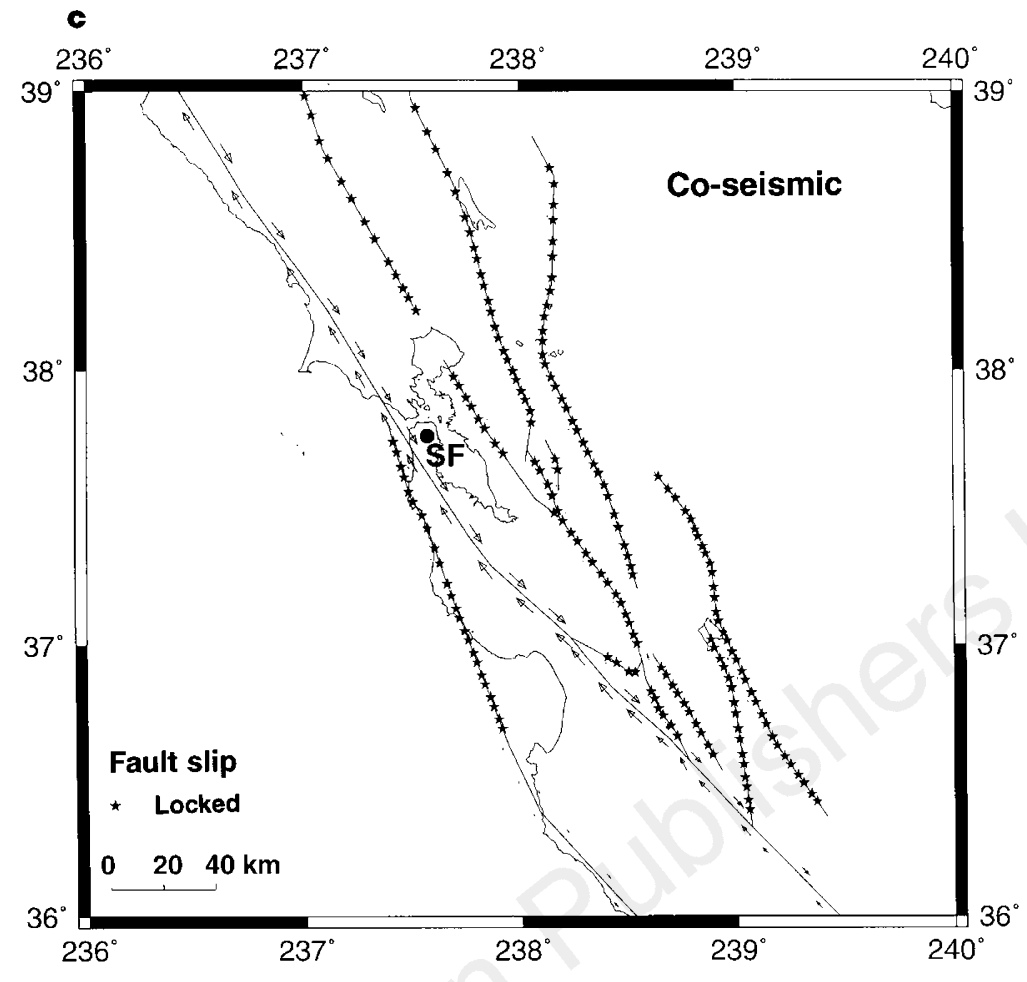

abruptly started on the segment of the San Andreas fault near Coalinga $^{30}$. But because this fault segment lies within the creeping section and little strain was accumulated ${ }^{2}$, the induced accelerated slip was small.

Given that the crust is compressible, changes in the regional compression should be associated with changes in the lateral dimensions of the region. Thus the present model could, in principle, be tested against Global Positioning System (GPS) data from two or more well located stations. An order-of-magnitude estimate of the expected rate of change can be made as follows. We assume that a distance of $100 \mathrm{~km}$ separates two GPS stations located across the San Andreas fault system and the Coast Ranges. If the average magnitude of the regional changes in compression is $0.5 \mathrm{MPa}$ (similar to the average stress-drop in thrust earthquakes) and the average linear compressibility of the upper crust between the two stations is $4 \times 10^{-6} \mathrm{MPa}^{-1}$ (similar to that of granodiorite $^{31}$ ), a change of $0.2 \mathrm{~m}$ in distance between the two stations would be expected in one earthquake cycle. If, further, the inter-seismic interval is $200 \mathrm{yr}$ and the rate of change in distance is constant, a rate of change of $1 \mathrm{~mm} \mathrm{yr}^{-1}$ in distance between the two stations might occur during the inter-seismic interval. The considerable uncertainties in the many assumptions may cast doubt on the correctness of this estimate. But if the orders of magnitude of the assumed quantities are correct, the present model may be tested given $\sim 10$ yr of continuous GPS data across the Coast Ranges.

Received 21 October 1996; accepted 3 June 1997.

1. Thatcher, W. in The San Andreas Fault System, California. Prof. Pap. US Geol. Surv. 1515, 189-205 (1990).

2. Lisowski, M., Savage, J. C. \& Prescott, W. H. The velocity field along the San Andreas fault in central and south California. J. Geophys. Res. 96, 8369-8389 (1991).

3. Brown, R. D. Jr in The San Andreas Fault System, California. Prof. Pap. US Geol. Surv. 1515, 83-113 (1990).

4. Kelson, K. I., Lettis, W. R. \& Lisowski, M. in Proc. 2nd Conf. Earthquake Hazards in the Eastern San Francisco Region (eds Borchardt, G. et al.) 31-33 (Spec. Publ. 113, Calif. Division Mines \& Geol. Sacramento, 1992).

5. Mount, V. S. \& Suppe, J. State of stress near the San Andreas fault: Implications for wrench tectonics. Geology 15, 1143-1146 (1987).

6. Zoback, M. D. et al. New evidence on the state of stress of the San Andreas fault system. Science 238 1105-1111 (1987).

7. Harbert, W. Late Neogene relative motions of the Pacific and North America plates. Tectonics 10, 1-15 (1991).
8. Page, B. M. in Proc. Conf. Earthquake Hazards in the Eastern San Francisco Bay Region (eds Hart, E. W., Hirschfeld, S. E. \& Schulz, S. S.) 1-10 (Calif. Division of Mines \& Geology, Sacramento, 1982).

9. Aydin, A. in Prof. Conf. Earthquake Hazards in the Eastern San Francisco Bay Region (eds Hart, E. W., Hirschfeld, S. E. \& Schulz, S. S.) 11-21 (Calif. Division Mines \& Geol., Sacramento, 1982).

10. Namson, J. S. \& Davis, T. L. Seismically active fold and thrust belt in the San Jaoquin Valley, Central California. Geol. Soc. Am. Bull. 100, 257-273 (1988).

11. Jones D. L. et al. Neogene transpressive tectonics of the California Coast Ranges. Tectonics 13, 561-574 (1994).

12. Ekstrom, G., Stein, R. S., Eaton, J. P. \& Eberhart-Phillips, D. Seismicity and geometry of a 110-km-long blind thrust fault: 1 . The 1985 Kettleman Hills, California, earthquake. J. Geophys. Res. 97, 4843-4864 (1992).

13. Minster, J. B. \& Jordon, T. H. Present-day plate motions. J. Geophys. Res. 83, 5331-5353 (1978).

14. DeMets, C., Gordon, R. G., Argus, D. F. \& Stein, S. Current plate motions. Geophys. J. Int. 101, 425478 (1990).

15. Argus, D. F. \& Gordon, R. G. Current Sierra Nevada-North American motion from very long Baseline Interferometry: implications for the kinematics of the western United States. Geology 19, 1085-1088 (1991).

16. Wang, C. Y., Cai, Y. \& Jones, D. L. Predicting crustal failure in the Greater San Francisco Bay area. Geology 23, 771-774 (1995).

17. Brocher, T. M. et al. Seismic evidence for a lower-crustal detachment beneath San Francisco Bay, California. Science 265, 1436-1439 (1994).

18. Fuis, G. S. \& Mooney, W. D. in The San Andreas Fault System, California. Prof. Pap. US Geol. Surv. 1515, 207-238 (1990).

19. Williams, C. F. \& Galanis, P. S. Jr Heat-flow measurements in the vicinity of the Hayward Fault, California. (Open File Rep. 94-692, US Geol. Surv., Reston, 1994).

20. Kohlstedt, D. L., Evans, B. \& Mackwell, S. J. Strength of the lithosphere: Constraints imposed by laboratory experiments. J. Geophys. Res. 100, 17587-17602 (1995).

21. Berry, F. A. F. High fluid potentials in California Coast Ranges and their tectonic significance. Bull. Am. Assoc. Petrol. Geol. 57, 1219-1248 (1973).

22. Jennings, C. W. Fault map of California with locations of volcanoes, thermal springs, and thermal wells. (Geol. Map 1, scale 1:750,000, Calif. Division Mines \& Geol., Sacramento, 1975).

23. Graymer, R., Jones, D. L. \& Brabb, E. E. (Open File Map 94-622, US Geol. Surv., Reston, 1994).

24. Lachenbruch, A. H. \& Sass, J. H. Heat flow and energetics of the San Andreas fault zone. J. Geophys. Res. 85, 6185-6222 (1980).

25. Braun, J. \& Beaumont, C. Three-dimensional numerical experiments of strain partitioning at oblique plate boundaries: Implications for contrasting tectonic styles in the southern Coast Ranges, California, and central South Island, New Zealand. J. Geophys. Res. 100, 18059-18074 (1995).

26. Thatcher, W. Nonlinear strain buildup and the earthquake cycle on the San Andreas fault. J. Geophys. Res. 88, 5893-5902 (1983).

27. Scholz, C. H. The Mechanics of Earthquake Faulting (Cambridge Univ. Press, 1990).

28. Scholz, C. H. The Black Mountain asperity: seismic hazard of the southern San Francisco Peninsula, California. Geophys. Res. Lett. 12, 717-719 (1985).

29. Jaume', S. C. \& Sykes, L. R. Evolution of moderate seismicity in the San Francisco Bay region, 1850 to 1993; seismicity changes related to the occurrence of large and great earthquakes. J. Geophys. Res. 101, 765-790 (1996)

30. Mavko, G. M., Schulz, S. \& Brown, B. D. Effects of the 1983 Colinga, California earthquake on creep along the San Andreas fault. Bull. Seismol. Soc. Am. 75, 475-489 (1985).

31. Birch, F. Handbook of Physical Constants. Mem. Geol. Soc. Am. 97, 97-174 (1966).

Acknowledgements. We thank D. Jones for discussions, and E. Jones and C. Beaumont for comments.

Correspondence should be addressed to C.-y. W. 